\title{
Conflicting Worldviews in the Classroom: The 'Holdeman' Mennonite School Trial $1978^{1}$
}

\section{Andrew Pemberton-Pigott}

ABSTRACT: Many historians and sociologists have noted that the classroom often becomes the battleground for conflicting social values. The 1978 Regina vs Wiebe trial in Alberta was a clear example of stresses caused by changing values in a pluralistic society. Regina vs Wiebe reveals a struggle between three contrasting worldviews: Mennonice traditionalism, Mennonite modernism, and state secular humanism. The result forced provincial approval of independent schools on the grounds of religious freedom. This study outlines the legal, religious, and philosophical themes of the trial and uncovers underlying denominational tensions.

On the 18 th of January 1978, Elmer Wiebe stood in the witness box in a provincial court at Three Hills, Alberta. He and forty-four fellow members of the Church of God in Christ, Mennonite faced charges -under the truancy regulations for removing their children from the nearby public school in the town of Linden. When asked to explain these actions, Wiebe replied that it was to protect the very souls of their children:

[T] he best years of their [lives], the molding years, were being lost because they were too close in contact with the low standards of today ... we finally realized, if we don't do something as parents, we will lose our only eternal heritage which is our children ... we feared we would lose them; they would lose themselves and leave God. ${ }^{2}$

The outcome of the Regina $v$. Wiebe trial changed the administration of education in Alberta. The provincial government was forced to create a new category of private unfunded schools. The government also recognized the right of parents and religious groups to control the ideology and method of their children's education to a much greater degree in their own private schools. Regina v. Wiebe was, in essence, a local conflict over community power which had wider impact because it was driven by three contrasting streams of social values: Mennonite traditionalism, Mennonite Brethren modernism, and increasingly influential state secular humanism. The situation in Linden was provoked by divisions between two local Mennonite groups. The Mennonite 


\section{Past Imperfect}

Brethren sought to maintain a modern program of education for their children. The Church of God in Christ, Mennonite congregation had removed their children from such a program in reaction to what they believed to be satanic forces of irreligious humanism. Yet ironically, in the end, their actions were sanctioned by the state because of humanistic trends of tolerance and protection of individuals and minorities.

Four and a half months before the trial, one hundred and twenty-one students who had been attending the public school in Linden were instead enroled in the Kneehill Christian School just outside the town. It was one of seven schools set up in Alberta in the 1970s by the Church of God in Christ, Mennonite - more commonly known as the "Holdeman" church. ${ }^{3}$ Kneehill was a new, soundly constructed building with five teachers and two teacher's aides. The classes used a curriculum for the most part similar to that required by Alberta Education, and the school enjoyed strong support from the parents. But the Three Hills school board charged that Wiebe and his fellow church members were flouting two pieces of legislation: the School Act, which required all children to attend a government-recognized school; and the Department of Education Act, which required that all children be taught by government-approved teachers. Neither of these requirements was in force at the Kneehill school.

Such an illegal action was contrary to normal Holdeman practice. They believed in obedience to the state, but they also believed that the very survival of their communities was at stake. Their congregations were held to be the last oases of true spirituality in a desert of heresy, unbelief, and worldly distractions. The Holdemans believed that their right to control their children's education had been established by Christ and the disciples, nurtured through centuries of Catholic domination by the non-conformist movements of the Middle Ages, won in the fiery martyrdoms of sixteenth-century Switzerland and Germany, renewed by an American reformer in 1859, and guaranteed by the Canadian government in 1873. As the Holdemans saw it, they were defending nothing less than their entire spiritual heritage.

The Holdemans, like other Mennonites, trace their "recent" roots back to the Anabaptists of Swiss-German Reformation in the 1520s. Anabaptists considered themselves neither Catholic nor Protestant but a third stream that perpetuated the true Christianity of the New Testament churches. The Anabaptist vision of society was founded on a strict separation of church and state. Salvation, they believed, did not come from church-administered sacraments, nor from faith alone, but from living in simple and peaceful purity as the earliest Christian believers were thought to have lived. All forms of warfare and contention were to be unhesitatingly rejected. Individuals could not be born 


\section{The 'Holdeman' Mennonite School Trial 51}

into the church but were required to testify to their own conviction in the rite of adult baptism. The church was to be a voluntary community united in Christian love and freed from the strife and petty cares of the world.

In the 16th and 17th centuries, the Anabaptists were severely persecuted by the governments of Switzerland and many of the southern German territories. They were attacked as heretics by Catholic and Lutheran state churches alike. Such hostility reinforced their conviction that the world and all those associated with it were inevitably antagonistic to the "true church". The persecutions also reinforced existing Anabaptist divisions that had arisen out of different interpretations of the New Testament. Scattered and repressed, the earliest Anabaptist groups were the opening chorus of a long drama of fragmentation and schism. One large group of Anabaptists became known as Mennonites after Menno Simons (1496-1561), a prominent leader and prolific writer. $^{4}$

For Mennonites today, the importance of the education of children stems directly from the founding principles of Anabaptism. They believe that humans are inclined towards sin and hence need spiritual redemption. To be fully human requires knowing and following the will of God in order to have the proper relationship to God, to the community, and to oneself. Adult baptism is a ritual signifying the voluntary decision to consecrate oneself to the will of God as expressed in the ideals of the Church. Because children cannot be born into the faith, it iscrucial to raise them with the proper spiritual ideals in order to give them the moral strength to enter the Church when mature. Their will must be restrained and guided by the will of their parents and their church leaders. ${ }^{5}$

The Mennonite emphasis on the moral guidance of children conflicts with the modern humanist view that all freedoms are desirable except those which interfere with the freedom of others. This difference has led some critics to accuse the traditional Mennonites of indoctrinating and isolating their children to ensure that they cannot transcend the limitations of their restricted communities and worldview. ${ }^{6}$ Traditional Mennonites believe, instead, that freedom is not the issue. The responsibility of the community is to create a spiritual world racher than merely reacting to a secular world created by others. ${ }^{7}$ The actions of the Linden Holdemans in 1977 are rooted in this stance.

The Mennonite desire for economic, religious, and educational independence set in motion a centuries-long series of emigrations that led through Holland, Friesland and Prussia, Russia, the United States, Canada, and, finally in this century, into third world nations such as Mexico, Bolivia, and Paraguay. Mennonite immigration into Canada 


\section{Past Imperfect}

from outside North America can be divided into four major waves. The most famous of these, from 1874 to 1880 , involved 7,000 Ukrainian Mennonites who responded to the federal government's invitation to settle land in Manitoba with the promise of freedom of religion and education. ${ }^{8}$

The Church of God in Christ, Mennonite originated in the mid19th century in the United States. Like other traditional Mennonite groups, it took its inspiration from the Bible, the writings of sixteenthcentury Mennonite leaders, and the guidance of church elders. And, like earlier Mennonite groups, it was trying to ensure nothing less than the survival of the true church of Christ; to be "in the world, but not of the world" and to live Christianity as the members believed it was intended to be lived. Their founder, John Holdeman (1832-1900), was raised in the Old Mennonite tradition, and became a minister in his twenties. He gradually became convinced that the mainstream Mennonites had become estranged from the correct forms of worship and lifestyle. The formation of the Holdeman church was only one of a number of splits among American Mennonites in the same period, and for much the same reasons.?

In 1859 Holdeman called for a renewal of the Anabaptist approach to the world. Modern followers believe that this was not a schism but rather a return to the true faith. ${ }^{10}$ Holdeman placed much emphasis on doctrinal purity, spiritual child-rearing, and simple lifestyle. He rejected any form of military or state service and all indulgence in worldly vanities, entertainments, and philosophies. ${ }^{11}$ John Holdeman's movement had little impact in its early years. Six years after his break with the Old Mennonites his flock numbered no more than twenty members. ${ }^{12}$ Success came in the late 1870 s when he began to make converts among the newly-arrived Russian Mennonites in Kansas and Manitoba. Visits to Manitoba in 1879 and 1881-2 proved fruitful, yielding one hundred and sixty-eight converts. At this point in its history, the Holdeman church was a rather unique combination of rigorous discipline and revivalist evangelical outreach. ${ }^{13}$ These contrary qualities did not last beyond the formative period. Eventually the pressures of adherence to strict codes of social behaviour in a liberalizing world would cause the Holdemans to turn increasingly inward for protection.

The first Holdemans arrived in Alberta at the turn of the century as part of a sizable wave of Mennonite settlement. Samuel Boese, a preacher from Oregon, homesteaded at Swallwell, near Linden, in 1902. Others came from Manitoba, and a church was built in 1904. Their numbers remained small: Linden was the only Holdeman congregation in the province until another was established in 1929 at Crooked Creek in the north-west. In 1940 these were still the only two 
Holdeman congregations listed out of 45 Mennonite churches in Alberta. Total Holdeman membership in the province was only 358. There were only four other Holdeman groups in Canada in 1940, all in Manitoba. ${ }^{14}$ No new congregations were added in Alberta until the 1950 s when groups began to escablish themselves in the Edburg and Spirit River areas.

As Linden was being settled in the early 20 th century, the freedom of education that had been promised to the Mennonites was under attack in Manitoba and Saskatchewan. Canadian Mennonites have a long history of educating their children according to their own standards of Christian piety, pacifism, and Anabaptist-Mennonite tradition. This practice, in itself, is not surprising, given the block settlement pattern of the prairies and the local nature of schools in the early years of the West. But for the Mennonites it was a matter of principle as much as practicality. In the 1870 s the Manitoba Mennonites were generally able to retain their religious traditions with the aid of block settlements, their own independent schools, and the continued use of German in worship, education, and everyday life. But their distinctiveness became threatened by increasing British-Canadian immigration into the province and rising pressures of assimilation in the late 19 th century. ${ }^{15}$ The battle for the Canadian character was to be fought in the classroom.

Educators in the early 20th century were not taking special aim at Mennonites. Assimilation was part of a widespread change in education in North America. The first stage was the 19th century establishment of denominarional schools run by and for the different churches. The second stage began in the late 19 th century when the great majority of these religiously restrictive schools were replaced over the next halfcentury, for the most part, with nondenominational, Christian-oriented public schools, particularly at the elementary level. This stage was never fully established before the schools were overtaken by yet another change in the mid-20th century; this time to a philosophy nominally Christian but essentially secular and nationalistic. ${ }^{16}$

The First World War greatly intensified the pressures of assimilation. Mennonite-run schools fell victim to anti-German feelings in 1914. Mennonites felt increasingly uneasy with the nationalistic and militaristic measures that crept into the public schools during the war, such as the compulsory use of flags, pictures of George $V$ in every classroom, the singing of the national anthem, and the use of patriotic songs and literature. Manitaba made school attendance at accredited public schools mandatory for the first time in 1916. The Mennonites reacted strongly: public schools in Mennonite areas dropped from 60 in 1916 to 30 in 1918 as Mennonites returned to private church schools. ${ }^{17}$

The issue came to a head in 1919 when John Hildebrand was charged 


\section{Past Imperfect}

under the School Attendance Act for keeping his daughter in a Mennonite private school (Rex $v$. Hildebrand [1919]). ${ }^{18}$ Hildebrand's defence hinged on the promises of religious and educational freedom made by the federal government. These, it was argued, should take precedence over provincial attendance regulations. The court rejected his defence on the grounds that the federal Order-in-Council of 13 August 1873, which guaranteed Mennonites freedom of religion and education, was promulgated three years after the creation of Manitoba in 1870, and thus invalid. A second question centred on a difference in wording between a letter of guarantee sent to the Mennonites on 23 July 1873 and the wording of the Order-in-Council issued three weeks later. The subtle difference was interpreted to mean that Mennonite education was subject to provincial regulation. ${ }^{19}$ The situation was similar in Saskatchewan. Public schools were seen as the molding-place of AngloSaxon civilization, and met similar Mennonite resistance. ${ }^{20}$ There were over 5,000 prosecutions of Mennonites over school attendance in Saskatchewan between 1920 and $1925 .^{21}$

Mennonites in Manitoba and Saskatchewan were thus forced to choose between compromising their strong principles on education or emigrating. Most chose to stay and adapt, but many traditionalists left for Mexico and Paraguay between 1922 and 1927. The exodus in the $1920 \mathrm{~s}$ was the second Mennonite emigration in 50 years over the issues of schools and government interference. Those who remained behind adapted as best they could. In the large rural block settlements the church and community were able to retain a large measure of influence on both the school and the children.

In Alberta the Mennonites were fewer in number and more widely dispersed. Where there were no public schools, there was no mandatory attendance. An isolated and rural group like the Holdeman congregation in Crooked Creek could run their own school without governmental interference. ${ }^{22}$ In many cases the public schools were in such poor condition and the children so dispersed that attendance of any kind was a welcome phenomenon to the government. ${ }^{23}$ A UFA goal of the times was "Grade Eight for Every Boy and Girl". It is interesting, however, to note that a landmark Alberta school attendance case (Rex ex rel Brooks v. Ulmer [1923]) involved another German-speaking church -- in this case, the Lutherans. The Supreme Court of Alberta found the defendant guilty on the same grounds as Rex $v$. Hildebrand: that provincial attendance regulations could not be overruled. One of the judges noted in his summation:

[the Lutherans] appear to have thought that in coming to this country they were coming to a land where ... the 
liberty of the individual prevailed. They are unfortunately mistaken ... There is no protection ... unless the Legislature sees fit to expunge this tyrannous provision from the school law, or at least unless the Department adopt a less tyrannical policy of adminstration of the law. ${ }^{24}$

Financial exigencies on the prairies in the 1920s and 1930s forestalled governmental visions of educational control for many years. Funds were severely limited, and, in some places, the enrolments were declining. Mennonite private schools, however, held their own. After the worst of the 1930s Depression, their numbers increased, fuelled by Russian immigration and an internal response to a North America-wide rise of Christian fundamentalism. ${ }^{25}$ One Mennonite observer later referred to this expansion of the 1930s as the beginning of an "educational renaissance" in North America. ${ }^{26}$

In Alberta the rise of Mennonite schools was in part a response to the new educational programs and standards introduced by the new Social Credit government. Premier William Aberhart, himself a former teacher, took a strong personal interest in the public education system. In their first legislative session, the Socreds created larger school districts. Later they set higher standards for teachers, reorganized the teachers' association, and revamped the curriculum. To the traditional Mennonite churches, these changes meant less local control over policy, buildings, teachers, and content. ${ }^{27}$ Each measure was seen as a direct attack on their traditional educational methods. Public schools in which "greater emphasis was placed on the needs of the individual students" were anathema to the Holdemans, who insisted rather on training the child to follow the will of God.

Education spending by the Alberta government was again reduced during World War II, but the post-war boom in prosperity and birthrates brought renewed vigour to the public school systems. The boom also brought new pressures of assimilation to Mennonites. The curriculum in most Mennonite schools became increasingly similar to that of the public system. This change was a combination of voluntary modernization and provincial regulation, and it reduced the need for a separate Mennonite education. From 1945 onwards, mainstream Mennonites were increasingly likely to send their children to public elementary schools. Of the five elementary schools established by the Brethren in Alberta between 1929 and 1937, four had closed by $1946 .^{28}$ Further education could be given in Mennonite high schools in each province and Mennonite colleges in Winnipeg and Kitchener -- or, increasingly, in the mushrooming public high schools and universities 
constructed for the baby boom generacion. During the 1950 s and 1960 s, at a time when public school construction was reaching all-time highs, only one Mennonite high school and one Bible college were founded in all of Canada. Rudy A. Regehr later described this period as one of financial struggles and a number of consolidations in the Mennonite schools. ${ }^{29}$

The Holdemans were also much affected by these post-war trends of pluralism and assimilation. North American Holdeman congregations were undergoing much stress in the post-war period from social changes. Their membership doubled in the 20 years after World War II, ${ }^{30}$ but they also suffered from severe internal dissension over proper lifestyle. Some members feared the intrusion of "worldly trends in houses, cars, clothing" and other enticements of a society increasingly focused on youth and materialism. There were many schisms, defections, and expulsions. ${ }^{31}$ As a direct result of these problems, in the 1950s, the Holdemans began to place a strong emphasis on the socialization of their children. Holdeman leaders called on the parents to ensure a spiritual home life. Books and study guides were imported from the U.S., and service projects were developed for yourh. ${ }^{32}$

The main threat to exclusive non-conformist churches was the government-regulated public school. The Holdemans believed that to protect their children it was essential to administer or influence elementary and junior high schools according to church standards. During the 1960 s, the Linden-area group was able to do this through consultation with the principal and the school board responsible for the Dr. Elliot public school which their children attended. The school responded to specific Holdeman concerns by avoiding the use of musical instruments, drama performances, inter-school competitive sports, and gym clothes in girls' physical education classes. Other items which contradicted Holdeman beliefs required compromise on both sides, for example the use of T.V. and radio, modern literature, and teaching the theory of evolution in science courses. ${ }^{33}$

These specific difficulties were overshadowed by a much greater problem of the general environment of the school. As in the rest of Canada, the percentage of the Holdeman population in the Linden area was declining. ${ }^{34}$ Increasing numbers of non-Holdeman students asked for sports, A/V equipment, and other missing programs. Peer pressure increased as the Holdeman percentage declined. The Holdeman parents were by now convinced that modern public schools, unconsciously or deliberately, fostered atticudes of disrespect, materialism, selfishness, and irreligion in their children. Ben Hiebert, a minister of the Linden church, stated at the trial: "We have co-operated and we have appreciated the schools of the past ... but today ... our children cannot cope 
wich it, and the risk is too high". ${ }^{35}$ The Holdemans believed that the sole alternative to the loss of their "only eternal heritage" was to set up and run their own school. The historical background of government prosecution and community control of education on the prairies explains, in part, the determination of the Alberta Holdemans to maintain control of their school curriculum, and their reluctant but determined challenge to provincial authority. ${ }^{36}$

This decision was not an isolated act by a single congregation but a reflection of measures taken elsewhere. In the late 1960 s and early 1970s a Holdeman campaign of renewal was taking place in many parts of North America. The Linden group was reportedly influenced to a large extent by literature, speakers and educational programs from the American church members. ${ }^{37}$ There were no Holdeman schools in North America in 1947. By 1969 there were three: two teaching grades 1 to 10 in Ohio and Georgia, and one high school in Kansas. Church leaders were contemplating opening up many more. ${ }^{38}$ In 1971 Clarence Hiebert wrote:

some leaders are considering entering a radically new socialization thrust which would indoctrinate their members and potential members (children of members) in an educational program appropriate to the times. They are speculating the emergence of some church-sponsored schools where they could control the enrire learning milieu. Whether this can happen or not is subject to question ... ${ }^{33}$

American religious private schools were encouraged by a landmark U.S. Supreme Court decision in 1972 on school atrendance regulations. ${ }^{40}$ This case nearly coincided with the push in the traditional Mennonite and Amish communities on both sides of the border to establish their own schools to help maintain their religious convictions. In 1972, Rudy A. Regehr predicted that Mennonite education would be greatly affected in the 1970s and 1980s by larger social pressures: the general movement of Christian ecumenism, a tendency for Mennonites to adopt middle-class spending habits, and the trend towards tolerant pluralism.

In Canadian society today there is no way in which a student can graduate from high school, even a Mennonite high school, without encountering many life styles, and belief and value systems. Given that assumption, it really does not seem reasonable that the purity of a particular Mennonite denomination can, or ought to be 
maintained in our schools. ${ }^{41}$

The Holdeman congregation in Linden began to consider seriously the establishment of a private elementary school in May of 1975, "in view of the fact that sister congregations in other States and Provinces had been doing this and were experiencing very satisfying and gratifying results". ${ }^{2}$ By 1978 there were at least three Holdeman schools operating in Alberta itself, and fifteen in other Canadian provinces. ${ }^{43}$ In addition, some non-Holdeman Mennonite communities had set up independent schools in the 1970 s in the districts of Spirit River, Newell, and Stirling. ${ }^{44}$

The training of teachers was more of a problem for the Holdemans than the training of their children. The Bible gave them guidelines and authority for raising children. ${ }^{45}$ What the Holdemans feared was that college-educated teachers would inevitably bring with them the secular, material, and "morally corrupt" influences of modern Western society. ${ }^{46}$ Even if the teachers, themselves, were of good character, the Holdemans objected to any "new liberal attitudes". and any educational program not firmly and manifestly rooted in the Christian faith. The goal of a Holdeman school was to teach 5 R's: reading, 'riting, 'rithmetic and, most importantly, Respect and Responsibility. The obvious solution was to use their own church members: individuals who demonstrated the requirements of God-given teaching talents and an upstanding personal character. ${ }^{47}$

The Linden group began to negotiate with the Alberta Department of Education for permission to set up their own private elementary school. This was refused because they insisted on using non-certificated teachers. The Holdemans, for their part, claimed that they were willing to accept provincial curriculum guidelines and departmental testing in their school, but not teachers from outside the congregation with different values. Walter Unruh, the chairman of the Kneehill school board, acknowledged during the trial that the Holdemans could accept certificated teachers provided that they met the board's other requirements: to be a 'born again' Christian and to possess both the aptitude and the desire to teach children. ${ }^{48}$

The problem was that Holdeman church members have rarely obtained a degree in any field. Traditional Mennonites have historically been strong advocates of literacy and basic education for all and of a lifelong study of Christian scripture and the works of the Anabaptist tradition. But many years of school education was generally considered both unnecessary and a cause of falling away from the true faith. The Holdemans generally discouraged any schooling beyond grade nine or ten. They were not completely opposed to higher education, but 
certainly extremely wary. ${ }^{49}$

Such education was possible for an individual if required to fulfil his or her God-given calling, but only with permission of the minister. ${ }^{50}$ When asked if there was any objection to the congregation sending a member to obtain certification, Walter Unruh replied: "the part that would be objectionable is the very detrimental influence in the university." " 11 Of the five Kneehill teachers in 1977, only two had complered high school, and only one possessed an education degree. This teacher, a woman, was subordinate to a younger male principal, in part because of her sex and in part because of her degree. ${ }^{52}$

A second flaw in the Holdeman proposals cited by the department of education was the heavy American content in the proposed curriculum. In facr, it had been borrowed directly from Holdeman schools in the United States. ${ }^{53}$ The Holdeman committee altered it considerably to make it more suitable for use in Alberta, but never received provincial approval. ${ }^{54}$ By 1976 the department of education was refusing to approve building plans or curriculum because of the standoff over teaching staff. Meetings with department officials and the Alberta School Trustees' Association were fruitless, and appeals to the minister of education and the premier brought no help. In May of 1976 the Holdemans finally advised the minister of education that they intended to proceed with the construction of the school and would open it on September 1977 with or without official permission. Construction of the school began in October 1976.55

This decision was in clear conflict with the laws of the land, which Mennonites scrupulously observe except when they believe that these laws conflict with the higher laws of God. Holdeman minister Ben Hiebert explained at the trial: "we realize that we did break regulations ... but we feel that under God and the Bible we can do noching less". ${ }^{56}$ The Kneehill Christian School opened September 1977 with 121 students from grades I to 10 , five teachers, and two teacher's aides. ${ }^{57}$

The educational bureaucracy was faced with a serious dilemma. By this time seven unregistered Holdeman schools were operating in Alberta, some for six years or more. ${ }^{58}$ Pressure was mounting from the Alberta Teachers' Association (ATA), which held that teachers' jobs and professional reputations were at stake. The ATA claimed that teacher certification was the prime safeguard of the quality of education. ${ }^{99}$ The Alberta School Trustees' Association (ASTA) was divided between those who felt that a new category of school should be created and those who felt that the Holdemans should be accommodated within existing private school regulations. ${ }^{60}$ Four of the seven local school boards affected by the Holdeman schools advised negotiation, outside supervision of the schools, and changing the legislation, rather 
than court action. ${ }^{61}$ Finally, the Three Hills board responsible for Linden voted to lay charges of truancy against the Holdeman parents. The church response was blunt: if their freedom of religion and schooling were denied they would leave the province. ${ }^{62}$

Elmer Wiebe, the man chosen as a test case, refused to hire a lawyer because of long-standing Anabaptist strictures against taking any hostile action against another individual -- even legal action. William Pidruchney, a lawyer and member of the cultural and heritage council of Alberta, gained permission to act as an amicus curiae, or Friend of the Court. This rare status was intended in law to allow someone to advise a judge, but in fact Pidruchney functioned as an unsolicited and unofficial defense counsel for Wiebe. ${ }^{63}$

The legal arguments were complex, and the attorney-general's office quickly intervened and took over the prosecurion. The case involved a number of sections and subsections of the School Act and the Department of Education Act. To put it simply, the Holdemans were charged under the truancy regulations of the School Act. ${ }^{64} \mathrm{But}$, according to the same act, children could be excused from attending a public school if they were "under efficient instruction at home or elsewhere". The Holdemans naturally claimed that their children were under efficient instruction. Their school, however, was not accredited because it lacked official approval as required by the Department of Education Act. ${ }^{65}$ Despite these regulations, the minister of education -- or the Department of Education on his or her behalf -- had the power to approve any school or program. Judge Hugh Oliver caustically commented in the pre-trial proceedings that "this whole problem could probably have been solved if the department had agreed to a private school." 66

The trial was held on the 18th and 19th of January, 1978 in Three Hills provincial court. The outcome might have been a straight repeat of Manitoba's Rexv. Hildebrand 1919 and Alberta's Rex v. Ulmer 1923, causing yet another Mennonite migration in search of educational freedom. In 1978, however, there was a new and potentially powerful legal challenge available to the Holdemans. Six years earlier the Lougheed government had promulgated the Alberta Bill of Rights, which recognized, among a number of "human rights and fundamental freedoms," the freedom of religion. More importantly, it also ruled invalid any other law of Alberta that conflicted with the Bill of Rights unless "expressly declared by an Act of the Legislature" ${ }^{67}$ This clause became one of the amicus curiae's main defense weapons. Pidruchney argued that no provincial Act had been issued to limit the freedom of religion clause in the Bill of Rights. The Bill of Rights must, then, take precedence over regulations of the School Act and the Department of Education Act. ${ }^{68}$ Pidruchney also pressed two other arguments. The 
first was that the court possessed the power to order Departmental approval of Kneehill and should do so. Second, he claimed that the Holdemans, as Mennonites, had been guaranteed educational independence by the federal government in 1873 , thirty-two years before the creation of Alberta.

The prosecution countered that whatever the merits of Kneehill school there had been a clear violation of rruancy regulations which should be enforced. It also questioned wherher the dispute over certificated teachers was a case of "deep religious conviction or the matter of personal preference". It suggested, pointing to testimony from Holdeman church members, that their preference was based on religious belief but was not an essential and inherent tenet of their religion. ${ }^{69}$ Finally, the prosecution argued that the Bill of Rights could not and did not guarantee "freedom of education" ${ }^{70}$

In his decision delivered on the 6th of February 1978, Judge Oliver found the accused not guilty on the grounds of freedom of religion. Oliver concluded that the School Act in this instance was "rendered inoperative by reason of the Bill of Rights because it denies to the accused, Elmer Wiebe, freedom of religion, guaranteed by s. 2 of the Alberta Bill of Rights." 71 The results came as a surprise to most observers. The attorney-general said immediately that his department would probably appeal the decision, and many hurried consultations took place between the ATA, the ASTA, and Department of Education officials. But, on March 3rd, Education minister Julian Koziak rose in the house to announce that the government would not appeal against its own Bill of Rights. Departmental regulations would instead be altered to provide for a new category of schools. Category 4, he said, would permit the operation of schools using non-certificated teachers, bur they would as a result receive no government funding. ${ }^{72}$

The Holdeman community was quite satisfied with this course of action, but it was immediately criticized by the presidents of the Alberta Teachers' Association and the Alberta School Trustees' Association. Bernie Keeler, execurive secretary of the ATA, commented later that the teachers were very disappointed with the government: "We think that this is sacrificing the right of these children to an education. The fact that it is sacrificed in the name of religious freedom [is not] adequate justification." It would, he said, lead inevitably to "less understanding, less tolerance, less religious freedom in the long run if these children are kept within their own ... strict religious beliefs and not allowed to compare those beliefs with those of others." 73 For the ATA there was a clear and immediate benefit in retaining union control of teacher certification, particularly in the late 1970s and early 1980s when recession and declining enrolments reduced the number of teaching 


\section{Past Imperfect}

positions. Murray Jampolsky, assistant executive secretary of the ATA claimed in 1977 that the basic issue was not religion, education, or economics, but certification. ${ }^{74}$ This is not to deny the ATA's genuine concern for the well-being of Alberta children. But in addition to this, a more subtle and more fundamental battle was being fought for control of the ideological socialization of the next generation. Keeler's comments illustrate four major social currents behind the conflict of the Wiebe trial: religious tradition, state control, modern ideology, and individual rights. ${ }^{75}$

The first of these involves the historical Anabaptist attitude of separation from the world and independence from the state. This attitude is an echo of earlier social structures when mobility and communication were limited and the church and family were the prime determiners of values and actions. To Keeler, this principle of separation was a limitation to be overcome; to the Holdemans, it represented a path toward eternal salvation.

The second theme is the growing intrusiveness of the state, demonstrated here in the increased monitoring and control of the education system. The power to make decisions on hiring, building standards, and curriculum has shifted increasingly from the local community to higher levels of authority, and the curriculum has become increasingly standardized by central planners. Essentially, the Holdemans won a concession in the area of hiring in order to control the ideology of their schools. Keeler thought that this was giving up too much state control. Alex Proudfoot, president of the ASTA during 1976-77, was more blunt: "When we get right down to the crunch, the child belongs to the state."76

The third aspect is the rising force of modern educational philosophy, the very root of the Holdeman decision to break away from the public system. The modern North American school has an inherent advocacy of certain philosophical, social, and political values and goals usually identified by the label of 'secular humanism'. The basic goal is to promote the best in Western civilization, encourage tolerance and cricical thinking, and avoid political and religious partisanship. Bernie Keeler was a strong supporter of secular humanism during his 20-year tenure as executive secretary of the ATA. He agreed in 1988 that his beliefs had been "in many ways reflected in Association policy." 77 To the Holdemans, the modern humanist program was at best foolish; at worst a devious attack on 'true' religion. This approach, they believed, would cause their children to "lose themselves and leave God". It was later observed that the idea of a "religiously neutral curriculum ... is a key to understanding the Mennonites' rejection of the public school system." 78 But this rejection was only part of much larger religious 
changes in North American education over the last 100 years. In the late 19th and early 20th centuries, just as in the last two decades, "a substantial number of individuals chose private schools because of religious beliefs. Then, as now, the values reflected in the public schools influenced this choice." in the 1970s and 1980s were set up by Christian groups who felt that the public system was not providing -- or worse, was hostile towards - a proper moral environment. Recent opinions on both sides of the private-public school question in Alberta have noted the underlying ideological conflict. Right-wing author and editor Ted Byfield identified the basic issue as neither funding nor politics, but a religious worldview versus an agnostic vision of an "Ideal Society". ${ }^{80}$ Sheldon Chumir, Liberal MLA from Calgary Buffalo, stated: "the central issue is the kind of society we wish to bequeath to our children and grandchildren". ${ }^{81}$

The fourth theme of individual rights has been much affected by anorher result of modern humanism, namely, the increased legal protection given in recent years to minority groups and individuals. This is exemplified in the first Canadian Bill of Rights in 1960, the Alberta Bill of Rights in 1972, the Canadian Charter of Rights and Freedoms in 1982, and the current national constitutional debates. The Holdemans, through a fortunate set of circumstances, were able to protect their schools by using this aspect of humanism against the larger threat of secular education.

The question that still remains is why court action was taken in Three Hills. It was well known in the provincial Department of Education that unregistered Mennonite schools existed in Alberta, and new Holdeman schools had been founded in other districts in 1976. Yet no charges had been filed against these parents. Why was it the Linden public school committee and the Three Hills district school board that first moved to lay charges?

One possible contributing factor was the existence in Three Hills of an irregular curriculum at the high school affiliated to the Prairie Bible Institute. This school was able to include much religious content because of earlier accreditation by the Socreds. This may explain in part why the Three Hills board of trustees pressed the Department of Education so hard to enforce standard provincial regulations. When it was clear to them that the Holdemans were determined to open Kneehill they called on the province for action: "Alberta education must deal with this matter on a Province-wide basis... It is the opinion of the Three Hills School Division Board that this matter simply cannot be ignored." ${ }^{82}$ Gerald Wilson, the superintendent of schools in Three Hills, felt that the Kneehill school would serve as a test area on behalf 
of the other divisions similarly affected. ${ }^{83}$

Another reason was the impact of such a large percentage of children removed from the Dr. Elliot school. Enrolment dropped from three hundred and twenty-five to one hundred and eighty-nine in one year. ${ }^{84}$ There was understandable concern over program variety, provincial funding, teachers who would be forced to transfer elsewhere, and the survival of the elementary and high schools in Linden. ${ }^{85}$ Yet the change was not entirely detrimental at first. Alberta Education provided what is known as a decreasing enrolment grant which allowed identical levels of funds in the first year and half funding in the next. Bus routes were adjusted accordingly, and empty classrooms were put to other uses. The school was also now free to provide programs, such as instrumental music, drama, and competitive sports, which had been restricted to mollify the Holdeman parents. The ratio of students to teachers was now fifteen to one, much better than the standard provincial rate. ${ }^{86}$

The conflict in Linden cannot be explained by differences between Holdeman and non-Mennonite community factions. One 1979 study examined the communities of Edburg, where conflict was substantial, and Blueberry in the Spirit River area, where there was no significant difficulty. The authors concluded that conflict was minimal in Blueberry because of the recent shared experience of pioneer farming in the 1950s, and the relatively small size of the Holdeman congregation there. In Edburg, the Holdemans were more numerous and were seen by non-Mennonites as 'outsiders' who arrived afterwards. ${ }^{87}$ These two considerations of community size and common arrival do not explain the situation in Linden. The Holdeman group did constitute 40 to 45 per cent of the Linden-area population and the public school students. But they were not recent arrivals, for it was they who had first opened up the land in 1902. Furthermore, it was not a case of Mennonites in conflict with other Christian denominations, for the population in and near Linden was approximately 80 to 90 per cent Mennonite. A very important factor, which has gone almost unmentioned in the court, the media coverage, and the subsequent analyses, is that the division in Linden was between two branches of the Mennonite faith. The 80-90 per cent Mennonite population of the area was split almost evenly between Holdemans and Mennonite Brethren. ${ }^{88}$ To understand the motives of the Three Hills and Linden school boards, it is necessary to consider the changing relationship between these two groups.

The Brethren were formed in 1860 in Russia, one year after the Holdemans in America. The Brethren had a similar combination of traditional values and a goal of revitalizing the Mennonite faith. Many emigrated to the American Midwest after 1874, with the first Canadian congregation established in $1888{ }^{89}$ At the time of the Kneehill school 
problem, there were 119 Brethren churches in Canada with 15,807 members, slightly more than in the United States. ${ }^{90}$ But, in contrast to the recent Holdeman movement away from worldly involvements, the Mennonite Brethren had been steadily moving towards a greater acceptance of modern activities and lifestyle. They had increasingly come to accept radio and T.V., and entertainments such as dancing, movies and musical instruments. More importantly, children of Brethren parents increasingly attended public rather than private Mennonite schools and carried on ever further in their education. Peter Hamm wrote in 1987 that initial resistance within the church to change, secularization, and education "has given way in the last decade to widespread acceptance of, and adjustment to, change." Although the Brethren are not as yet entirely acculturated into the larger society, Hamm identified the years from 1965 to 1975 as ones of "assimilation and convergence". ${ }^{11}$

David J. Goa, curator of Folk Life at the Provincial Museum of Alberta, confirmed this trend. In his opinion the Brethren had become increasingly influenced by the twentieth century evangelistic movement and were in the midst of casting off many of the traditional Mennonite values and forms of worship. Many Brethren churches had in recent years become community churches that catered to a larger and more diverse congregation. The majority of teachers at the Dr. Elliot school, and the majority of school board trustees, were Mennonite Brethren who were increasingly allowing modern changes in the Linden schools. The Holdemans, however, were in the middle of a revitalized trend to traditionalism. The church leaders were requiring the members to shed all possible contacts with banks, lawyers, state agencies, and the business world. Many Holdemans, who had been running small agriculcural implement factories in Linden or involved with marketing boards, sold their businesses and produce quotas cheaply to the Brethren and returned to farming. To the Holdemans this withdrawal from the commercialized and regulared world was not a retreat but rather a renaissance. According to Goa, they saw the Brethren as tainted with materiality and modernity, and they constantly "witnessed" to the Brethren members to join their movement of purification. The Brethren, Goa commented, understandably felt "personally offended in their religious identity." 22

Peter Hamm's study of the Brethren concluded that due to "the rapid assimilation in recent decades, the tension of 'being in the world but not of the world' has been accentuated and has contributed to the current identity crisis." ${ }^{93}$ A number of Holdemans, who had abandoned or been expelled from the Linden congregation, joined the Brethren church and were subsequently shunned by their former coreligionists. ${ }^{94}$ 
The Holdeman congregation, by actively withdrawing from worldly activity and exhorting their neighbours and relatives to do the same, exacerbated an existing internal tension within the Brethren. The stress led to an extraordinary situation for descendants of Anabaptism: a Mennonite Brethren school principal, the Brethren school committee, and a predominantly Brethren school board asked the government to take fellow Mennonites and relatives to court.

The Three Hills board mentioned the community polarization in Linden. A letter of January 1977 to the Department of Education noted a "very heavy strain being placed on intra-community relations." ${ }^{55}$ Six months before Kneehill opened, the board's estimates of the number of children likely to attend ranged from 114 to 140 . Notes from an ASTA meeting in February stated that the "count varies because of possible internal dissension among Mennonites." ${ }^{\text {"96 }}$ Gerald Wilson spoke after the Wiebe trial of great tensions and separations within the community as relatives, lifelong friends, and fellow church members took opposing sides and changed churches. Wilson believed that the cause of this acrimony was the establishment of Kneehill. The impact, he said, "carries beyond the school issue -- it becomes a community issue." ${ }^{97}$ But in fact it was already a community issue. The founding of Kneehill was the result of theological and social concerns that had been moving inevitably towards a major confrontation. It is not surprising that the dispute centred around schools, for "the school is frequently the focus of community-based conflict." ${ }^{88}$ Schools have become a major centre of community activity in North America, particularly since World War II. In Linden, the school was the largest remaining area of interaction in an increasingly divided community. In Goa's opinion, "the school issue became a focus point for who is living within the disciplines of the tradition and who is not." 99 Of all the school boards affected by the Holdeman actions, it was Three Hills which most insistently pleaded for the ATA, the ASTA, and the Department of Education to resolve the conflict, "either by changing legislation or enforcing the School Act." 100 This persistence reflected more than numbers. It was the desire of a torn community and divided churches to have a crippling problem decided by an outside authority.

The Kneehill school stands as a symbol of the central beliefs of the Anabaptist tradition, as well as a crucial tactical move by the Holdemans to preserve what they consider to be the disciplines of a holy and vital Christian life. They continue to believe that they, alone, represent the "true church" established by Christ and the early disciples. Creating a school was an attempt to regain their traditional control and responsibility over the education of their children -- their "only eternal heritage". ${ }^{101}$ The Church of God in Christ, Mennonite was founded on 
the principle of the separation of church and state and holds that education is the responsibility of the church. The separation of church and state is not a fundamental precept of Canadian government, for the B.N.A. Act enshrines a double system of Protestant and Catholic school systems. Over the years, however, the 'Protestant' system has become increasingly standardized, centralized, and secularized; religiously neutral, but philosophically secular and humanist. This is acceptable to the great majority of parents and educators; indeed, it is claimed to be the solurion to ethnic, economic, racial, and religious prejudice and hatred. ${ }^{102}$ To the Holdemans it represented nothing less than a satanic attack on the last fragment of the true Church. They were willing to accept some measure of provincial guidance in such a vital area, but not absolute state authority. Section 93 of the B.N.A. Act made Canadian education a provincial responsibility. In the early years of the twentieth century, this authority was used by the Western provinces to limit private religious schools. Today that same authority permits provincial flexibility. It was an easy matrer for Alberta to change its relevant legislation once the political will to do so was established.

The founding of Kneehill school was part of a national increase in private school enrolment in the late 1970s and early 1980s, a phenomenon which took place all across Canada in spite of widely different provincial legislation and funding policies. ${ }^{103}$ But it was also part of a definite and deliberate traditionalist revival movement within the Holdeman church, a "purifying" of the lifestyle and character of its members and a protection of its young. In Linden this came into sharp conflict with another group of Mennonites who were moving in a different direction. As William Pidruchney stated in his trial summation,

[i] $\mathrm{C}$ is not for us to determine whether or not society is deteriorating, but I chink we can all testify to the fact that sociery certainly changes. For some of us these changes may be absolutely acceptable and desirable ... but this is not necessarily the sicuation in so far as the next man is concerned. ${ }^{104}$

The result of the Wiebe trial was protection of the Holdeman traditions of interdependent church, school, and family. Barring any evidence of large-scale harm to their pupils, Holdeman schools are likely to remain in their current form in Alberta in the near future. Their long-term survival, however, depends upon the continued tight mutual support of church and family in a rural, agricultural lifestyle. Two 1977 studies of Mennonite students questioned the long-term effects of religious education on their future 'religiousness'. The surveys showed that 
family values and friends of the same denomination were much more important factors in the religious orthodoxy of students. ${ }^{105}$ The number and very existence of Holdeman schools depends a great deal upon the survival of the close-knit Holdeman communities and whether their values can continue to be transmitted to their children in the midst of an increasingly intrusive and influential world. 
The 'Holdeman' Mennonite School Trial 69

\section{APPENDIX: HOLDEMAN STATISTICS}

HOLDEMAN COMMUNITIES IN ALBERTA, 1990

\begin{tabular}{|c|c|c|c|c|}
\hline Location & $\begin{array}{l}\text { Adult } \\
\text { Membership }\end{array}$ & School & $\begin{array}{l}\text { Students } \\
1978-79\end{array}$ & $\begin{array}{l}\text { Students } \\
1989-90\end{array}$ \\
\hline Wanham & 54 & Heart Valley & 15 & 32 \\
\hline Blueberry & 59 & Northern Lights & 13 & 30 \\
\hline Crooked Creek & 163 & Rosedale & 65 & 70 \\
\hline Fr. Vermilion & 60 & Vermilion Peace & 13 & 29 \\
\hline Dewberry & 40 & Lakeland & 9 & 40 \\
\hline Stertler & 78 & Lakeview & 28 & 29 \\
\hline Edbor & 2 & (North)Countryside & 27 & 37 \\
\hline (Meecing Creok) & & South Couryside & 22 & $*$ \\
\hline Linden & 362 & Knoctill & 96 & 86 \\
\hline Pincher Creek & 76 & Rocky View & 0 & 20 \\
\hline TOTALS: & $\overline{919}$ & & $\overline{288}$ & $\overline{373}$ \\
\hline
\end{tabular}

* Some schools had been operating unofficially since 1976.

** Closed 1979. North Countryside and South Countryside merged in 1979 to form Countryside school.

CATEGORY 4 PRIVATE SCHOOLS IN ALBERTA:

SELECTED YEARS, 1978 - 1990

\begin{tabular}{lcccccc}
\hline & $1978-79$ & $1980-81$ & $1981-2$ & $1983-4$ & $1985-6$ & $1989-90$ \\
Holdeman Schools: & 8 & 8 & 8 & 8 & 9 & 9 \\
Other Caregory 4 Schools: & $\frac{2}{10}$ & $\frac{8}{16}$ & $\frac{9}{17}$ & $\frac{9}{17}$ & $\frac{26}{35}$ & $\frac{21}{30}$ \\
Total Category 4 Schools: & & & & & &
\end{tabular}

Sources:

Alberta Deparment of Educarion, Approved Private Schools in Alberta (and similar tirles), $1978-79,1980-81,1981-82,1984,1986$

Alberra Education Information Services (1989-90 Caregory 4 figures)

Yearbook of Church of God in Christ, Mennonite (St. Anne, Man: Gospel, April 1990 [from phone interview with Carol Isaac, teacher ar Lakeland school in Dewberry, 3 May 1990]) 


\section{NOTES}

${ }^{1}$ I wish to thank professors David J. Goa and John J. Bergen for their generous assistance in providing research materials and their subsequent comments. Any errors which remain are, of course, mine alone. I also wish to express gratitude to my wife Valerie, who has been unfailingly supportive throughout.

${ }^{2}$ Regina v. Wiebe, 1978, photocopy of trial transcript, 52-6. My thanks to David J. Goa for providing this material.

3 While acknowledging the preference of the Church of God in Christ, Mennonite for their official name, I have used the term "Holdeman" throughout this essay solely for the sake of brevity.

${ }^{4}$ A useful survey of modern Mennonite groups can be found in Arthur Carl Piepkorn, Profiles in Belief: The Religious Bodies of the United States and Canada, vol 2, Protestant Denominations (San Francisco, 1978).

${ }^{5}$ William Klassen, "The Role of the Child in Anabaptism," in Mennonite Images, ed. Harry Loewen (Winnipeg, 1980), 17-32

${ }^{6}$ See for example articles by William Thorsell and Ted Horton, Edmonton Journal, 28 Feb. 1978.

${ }^{7} \mathrm{I}$ am indebted here to David J. Goa, particularly for his distinction between the creativity of "traditional" religious groups and the rigidity of "conservative" groups.

${ }^{8}$ E.K. Francis, In Search of Utopia: The Mennonites in Manitoba (Altona, Manitoba, 1955)

'See for example Peter M. Hamm's account of the formation of the Mennonite Brethren in Continuity and Change Among Mennonite Brethren (Waterloo, Ontario, 1987), 46-54.

${ }^{10}$ Elmer Wiebe stated that Holdeman "did not start a new Church, but he did revive those standards of the Bible of the Anabaptist vision" (Regina v. Wiebe, tr., 54). See Holdeman's statement on the "drifting away" of the Mennonite church in Clarence Hiebert, "The Holdeman People: a Study of God in Christ, Mennonite, 1858 - 1969" (Ph.D. thesis, Case Western University, 1971), 192. ${ }^{11}$ The 26 Holdeman Articles of Faith are listed in Hiebert, "Holdeman People," 594-607. See especially Article 19, "Nonconformity to the World". A large number of prohibitions promulgated berween 1903 and 1969 are listed on $582-$ 588.

${ }^{12}$ Hiebert, "Holdeman People," 74

${ }^{13}$ Francis, In Search of Utopia, 260-1

${ }^{14}$ Frank H. Epp, Mennonites in Canada, 1920-1940: A People's Struggle for Survival (Toronto, 1982), 269-289. See Hiebert, "Holdeman People," for the locations of Holdeman communities in North America.

${ }^{15}$ E.K. Francis, "The Mennonite School Problem in Manitoba," Mennonite Quarterly Review 27 (1953), 204-36

${ }^{16}$ Patricia M. Lines, Treatment of Religion in Public Schools and the Impact of Private Education (Denver, 1984) 
${ }^{19}$ The two paragraphs are (quoted in 3 Western Weekly Reports [1919] 289):

The fullest privilege of exercising their religious principles is by law afforded to the Mennonites, without any kind of molestation or restriction whatsoever; and the same privilege extends to the educarion of their children in schools (letter of guarantee, 23 July 1873. irem \# 10).

That the Mennonites will have the fullest privilege of exercising their religious principles, and educaring their children in schools, as provided by law, withour any kind of molestation or restriction whatever (Order-in-Council, 13 August 1873, item \#10).

${ }^{20}$ See rhetorical examples in Epp, Mennonites in Canada, 99, $131 \mathrm{n} .31$

${ }^{21}$ Tabled in Ibid., 103

${ }^{22}$ The percentage of Mennonices living in rural areas was extremely high at this rime, especially among groups who followed a simple agricultural lifestyle as an article of faith. Census figures indicate that the proportion of urban Mennonites, including those in small towns, never rose above 50\% before 1981 .

${ }^{23}$ Paul Voisey, Vulcan: The Making of A Prairie Community (Toronto, 1988), $177-8$

24 Rex ex rel Brooks v. Ulmer [1923] I Western Weekly Reports, 1-28 ar 27-8. See also discussion by RG. Fowler, Regina v. Wiebe, tr., 223-5.

${ }^{25}$ Rudy A. Regehr, "A Century of Private Schools," in Call to Faithfulness: Essays in Canadian Mennonite Studies, eds. Henry Poetrcker and Rudy A. Regehr (Winnipeg, 1972), 106

${ }^{26}$ Mennonite Encyclopedia, "Mennonite Education," by Menno S. Harder

${ }^{27}$ John J. Bergen specifically mentions the loss of local control by the Holdemans after the formation of the larger school districts in "A Brief History of Private Schooling in Canada," Alberia Teacher's Association Magazine 66:4 (May/June 1986), 17.

${ }^{28}$ John A. Towes, A History of the Mennonite Brethren Church: Pilgrims and Pioneers (Fresno, Calif., 1975), 262-63

${ }^{29}$ Regehr, "Century of Private Schools," 109-111

${ }^{30}$ Author's estimated Canadian figures show an increase from 1,146 in 1947 to 2,017 in 1969.

${ }^{31}$ Hiebert, "Holdeman People," 314-323, 343

32 Ibid., 332-5

${ }^{33}$ Regina $\nu$. Wiebe, tr., testimony of Gerald Wilson, superintendent of the Three Hills school division, 13; Elmer Wiebe, 70; Cornelius Wiebe, 119. Lloyd Ratzlaff, principal of the Linden public school, interviewed in John J. Bergen, Mennonite Interviews: The Holdeman Mennonite School Question part 1, videotape, (Edmonton, University of Alberta Faculty of Education VTR 180, Augusr 1980), footage 190-207. Future references will be abbreviated as Mennonite Interviews 1 or 2 , followed by the foorage meter reading.

34 Principal Ratzlaff cited a decline from $70 \%$ circa 1975 to $40 \%$ circa $1976-7$ (Mennonite Interviews 1, 235). The Holdeman population in Canada grew from 1,036 in 1940 , to 3,209 in 1990 . Alberca's membership remained constant at one third of this, increasing from 358 to 1,005 in the same period. But as a 


\section{Past Imperfect}

percentage of registered adult Mennonites, the Holdeman membership decreased in the last 40 years. Canadian figures reveal a drop from $3.22 \%$ to $2.74 \%$; and for Alberta an estimated drop from $9.83 \%$ to $8.5 \%$. The Holdemans turned away from evangelistic conversion and other, more open, branches of Mennonites increased more rapidly (author's estimated figures derived from various sources). ${ }^{35}$ Regina $v$. Wiebe, tr., 60. See also 52-3, 60, 70-5, 118-9, and 122.

${ }^{36}$ The precedents were reviewed in Regina $v$. Wiebe, tr., 158-171 and Judge Oliver's oral judgement, 3 Western Weekly Reports, 10-18.

${ }^{37}$ John J. Bergen, interview with the author, Edmonton, 2 May 1990

${ }^{38}$ Hieber, "Holdeman People," 338, 506-7

${ }^{39}$ Hiebert, "Holdeman People," 506

${ }^{40}$ State of Wisconsin v. Jonas Yoder, 1972. Because of his demonstrated religious beliefs Yoder, an Amish, was permitted to withdraw his fourteen-year old son from the public school system to go to work at age fourteen. See William Pidruchney's comments in Regina v. Wiebe, tr., 192-7. Amish schools had increased from 60 in 1958 to 230 ten years later (Uria Byler, School Bells Ringing: A Manual for Amish Teachers and Parents [Aylmer, Ont; Lagrange, Indiana, 1969], preface).

${ }^{41}$ Regehr, "Century of Private Schools," 112

${ }^{42}$ Regina $v$. Wiebe, tr., testimony of Walter Unruh, 77

${ }^{43}$ B.C. two, Saskatchewan one, Manitoba eleven, and Ontario one; Regina v. Wiebe, tr., 117

\section{"4i Edmonton Journal, 4 Mar. 1977}

${ }^{45}$ Numerous Biblical references to parental responsibility were made during the trial (Regina v. Wiebe, tr., 50-1, 58, 61).

${ }^{46}$ Regina $v$. Wiebe, tr., testimony of Elmer Wiebe, 39, 76; Hiebert, "Holdernan People," 506-7

${ }^{47}$ Regina $v$. Wiebe, tr., testimony of Elmer Wiebe, 64-5; Ben Hiebert, 56; Elmer Wiebe, 53; Walter Unruh, 91-2

${ }^{48}$ Regina $v$. Wiebe, tr., testimony of Walter Unruh, 91-2. Unruh later admitted that the "new birth" was a matrer of preference rather than an absolute requirement (100-101). It is safe to assume that all Holdeman teachers, then and since, have been baptized members of the Holdeman church.

${ }^{49}$ Article 25 of the Holdeman creed states in part: "We are opposed to attending high schools and colleges in so far when they are conducted with pride and highmindedness, and where impure and false doctrine is taught and practiced" (Hiebert, "Holdeman People," 606). John Holdeman himself reportedly convinced many early converts in Kansas to abandon existing schools, and "the young people of his church remained uneducated" (Christian Krebbiel, quoted in Ibid., 131).

${ }^{50}$ Hiebert noted two Holdemans who, in 1950, advocated taking high school by correspondence in order to "avoid the questionable high school society" ("Holdeman People," 333). Some of che Alberta Holdeman schools had started out as correspondence schools in the 1970s.

${ }^{51}$ Regina v. Wiebe, tr., 107 
${ }^{52}$ David J. Goa, interview with the author, Edmonton, Alberta, 2 May 1990. The three adults who taught at the Rosedale school in Crooked Creek that same year had reached grade 10,11, and 12 respectively (Regina $v$. Wiebe, tr., 99; Edmonton Joumal, 10 June 1978).

${ }^{53}$ Regina v. Wiebe, tr., testimony of Cornelius Wiebe, 110

${ }^{54}$ Regina v. Wiebe, 79, 89-90, 110, 113-6. American content was still identified as a problem by a review in the mid-1980s (Alberta Education, An Audit of Selected Private School Programs [Edmonton, February 1985], 41-3). The Holdemans were using American Amish and other Christian materials that stressed practical mathematics and creationist science, and avoided mentioning T.V., radio, and modern gender relations.

${ }^{55}$ Regina $v$. Wiebe, tr., 78-88, 93

${ }^{56}$ Regina v. Wiebe, tr., 52, 58, 92-3

${ }^{57}$ Regina $v$. Wiebe, tr., 97

${ }^{58}$ Regina $v$. Wiebe, tr., 117, 179; Edmonton Journal, 4 Mar. 1977. See Appendix for details.

${ }^{59}$ Bernie Keeler, executive secretary of the ATA, in Mennonite Interviews 2, 255260

${ }^{60}$ Stan Maertz, executive direcror of the ASTA, in Ibid., 135-140

${ }^{61}$ Notes from meetings berween local boards, the Alberta Teachers' Association, the Alberta School Trustees' Association, and Department of Education officials, 26 Feb. 1977, 30 Mar. 1977, and 9 May 1977. My appreciation to John Bergen for providing photocopies of this material.

${ }^{62}$ Edmonton Journal, 8 Nov. 1977

${ }^{63}$ Edmonton Journah 9 Dec. 1977. See Judge Oliver's comments and interpretation of Pidruchney's role in Regina $v$. Wiebe, photocopy of inirial proceedings, 12 Jan. 1978, 8-19.

${ }^{64}$ Revised Statutes of Alberta (RSA) 1970, c. 329, s. 133-34 [amended 1971 c.100 S.16]

${ }^{65}$ RSA 1970, c.96, s.8 [amended 1971 c.100 s.20]. A good guide through the legal considerations is John J. Bergen, "Freedom of Education in a Religious Context: The Alberta Holdeman Privare School Case," Mennonite Quarterly Review 55:1 (Jan 1981), 75-85; and Judge Oliver's oral judgement in 3 Western Weekly Reports [1978], 37-62.

${ }^{66}$ Regina $v$. Wiebe, photocopy of initial proceedings, 12 Jan. 1978, 38

6 Statutes of Alberta, 1972, c. A-16, s. I(c), 2

${ }^{6 B}$ Regina v. Wiebe, tr., 182-197

${ }^{69}$ For example Walter Unnuh's testimony in Ibid., 100-101.

${ }^{70}$ Regina vs Wiebe, tr., testimony of R Smith, 205-210

${ }^{71}$ Regina v. Wiebe [1978] 3 Western Weekly Reports, 62. The trial arguments and judgement are briefly summed up in John J. Bergen, "A Decision That Shook Education in Alberta," Challenge in Educational Administration 18:1 (1978), 3336.

${ }^{72}$ Edmonton Journah 7 Feb. 1978, 17 Feb. 1978, 4 Mar. 1978. A later survey of the legislative changes brought about after the trial can be found in Woods 
Gordon, A Study of Private Schools in Alberta (Edmonton, 1984) report 3b, "Report of the Results of the Legal/Organization Surveys", 31-46.

${ }^{73}$ Bernie Keeler, in Mennonite Interviews 2, 261-271, 340-356

74 "Notes from meetings," 30 March 1977, 4; 9 May 1977, 4

${ }^{75}$ This analysis is adapted from John J. Bergen, ed., Whose Child? Whose School?, videotape, (Edmonton, University of Alberta Faculty of Education VTRF 166, August 1980), footage $115 \mathrm{ff}$.

${ }^{76}$ Quoted in Saint John's Edmonton Report, 14 Nov. 1977, 26

${ }^{7}$ Quoted in Aaron Bushkowsky, "The Man Behind the Vision," Alberta Teachers" Association Magazine 68:4 (May/June 1988), 36

${ }^{78}$ Elmer J. Theisson and L.J. Roy Wilson, "Curriculum in the Church-State Controversy: Are the Mennonites Justified in Rejecting the Public School Curriculum?," SALT: Journal of the Religious Studies and Moral Education Council (Alberta Teacher's Association, Spring 1979), 13

${ }^{79}$ Lines, Treatment of Religion, 42

${ }^{80}$ Ted Byfield, "The Religious versus the Agnostic View of Private Schools," Alberta Teacher's Association Magazine 66:4 (May/June 1986), 35

${ }^{81}$ Sheldon Chumir, "Vote No to Public Funding of Private Schools," Ibid., 21

${ }^{82}$ Lou Duigou, acting superintendent for the Three Hills district, to E.K. Hawkesworth, deputy minister of education, 28 Jan. 1977, cited in Regina $v$. Wiebe, tr., 179

${ }^{83}$ Regina v. Wiebe, tr., 33; Mennonite Interviews 1, 114-131

${ }^{84}$ Gerald Wilson gave these enrolment figures in Regina v. Wiebe, tr., 10. Only 121 pupils are cited for Kneehill school, leaving an unexplained difference of 15 . ${ }^{85}$ Lloyd Ratzlaff, the public school principal, and Fred Toews of the school committee mention their fears of schools closing in Mennonite Interviews 1, 2939 and 262-4 respectively. Their fears proved correct: Linden high school students were bused to nearby Acme, and junior high students moved from Acme to Linden.

${ }^{86}$ Principal Lloyd Ratzlaff in Mennonite Interviews 1, 285-90; Regina v. Wiebe, testimony of superintendent Gerald Wilson, 28-34

${ }^{87}$ Marilyn Assheton-Smith and Kelleen Toohey, "School-Centred Conflict: The Holdeman Mennonite Case in Alberta," Alberta Journal of Educational Research 25:2 (June 1979), 86-7. See also Assheton-Smith, in Mennonite Interviews 2, 160-245.

${ }^{88}$ Gerald Wilson, in Mennonite Interviews 1, 339-345

${ }^{89}$ J.C. Wenger, The Mennonite Church in America (Scottdale, Penn., 1966), 101 $13,237-39$

${ }^{90}$ Piepkorn, Protestant Denominations, 387

${ }^{91} \mathrm{Hamm}$, Continuity and Change, 168, 232

${ }^{92}$ David J. Goa, interview with the author, Edmonton, 2 May 1990

${ }^{9.3} \mathrm{Hamm}$, Continuity and Change, 237. The whole chapter "Assimilation and Identity Crisis" is useful. See also Epp, Mennonites in Canada, 447-88.

${ }^{94}$ Hiebert, "Holdeman People," 323. The Brethren parents of Lloyd Ratzlaff, 
principal of the Dr. Elliot public school, were former Holdemans.

${ }^{95}$ Lou Duigou to E.K. Hawkesworth, 28 Jan. 1977, cited in Regina v. Wiebe, tr., 179

$\%$ "Notes from meerings," 25 Feb. 1977, 2

${ }^{97}$ Mennonite Interviews 1, 350-61, 319-20

${ }^{88}$ Assheton-Smith and Toohey, "School-Centred Communiry Conflict," 77. John J. Bergen stated that "educational concerns are interrwined with those involving the whole fabric of any community" (Mennonite Interviews 1, 410). Fred Toews, a Mennonite Brechren member of the Linden public school committee, echoed the authors of Crestwood Heights by stating that in Linden "the community is built around the school" (Mennonite Interviews 1, 259).

"Goa interview

100 "Notes from meetings" 9 May 1977, 4. See also Duigou to Hawkesworth, 28 Jan. 1977, cired in Regina v. Wiebe, tr., 179.

${ }^{101}$ Regina v. Wiebe, tr., Elmer Wiebe's testimony, 52

${ }^{102}$ See for example Chumir, "Vore No to Public Funding of Private Schools," 22. ${ }^{103} \mathrm{See}$ Woods Gordon report cited in $\mathrm{n} 72$. Private school enrolment percentages in 1951 were $4.5 \%$ (Canada) and $2 \%$ (Alberta); they dropped to $2.28 \%$ and $1.1 \%$ respectively in 1971-2 and rose again to a $1984-5$ national high of $4.87 \%$ and a provincial peak of $3.11 \%$ in 1985-6. Recenc percentages indicate another decline: see Statistics Canada, Education in Canada, 1973 - 90; Alberta Education, Education in Alberta: Facts and Figures, (Edmonton, Dec. 1989).

${ }^{104}$ Regina v. Wiebe, rr., 186

${ }^{105}$ Donald B. Kraybill, Ethnic Education: The Impact of Mennonite Schooling (San Francisco, 1977), 98-105; Bruce E. Hunsberger, "A Reconsideration of Parochial Schools: The Case of Mennonites and Roman Catholics," Mennonite Quarterly Review 51:2(Apr 1977), 149-150. Hunsberger's study concluded that there was no clear relarionship berween parochial school training and later belief in college students. Kraybill concluded that "family background appears to exert the strongest influence" (103). 